\title{
Use of motorcycle in Brazil: users profile, prevalence of use and traffic accidents occurrence - a population-based study
}

\author{
Uso de motocicletas no Brasil: perfil dos usuários, prevalência de uso \\ e ocorrência de acidentes de trânsito - estudo de base populacional
}

Lenise Menezes Seerig ${ }^{1}$

Giancarlo Bacchieri ${ }^{1}$

Gustavo Giacomelli Nascimento ${ }^{2}$

Aluisio J D Barros ${ }^{1}$

Flávio Fernando Demarco ${ }^{1}$
${ }^{1}$ Programa de Pós-

Graduação em

Epidemiologia,

Departamento de Medicina

Social, Faculdade de

Medicina, Universidade

Federal de Pelotas (UFPel).

R. Mal. Deodoro 1160/3,

Centro. 96020-220 Pelotas

RS Brasil.

ffdemarco@gmail.com

${ }^{2}$ Programa de Pós-

Graduação em Odontologia,

Faculdade de Odontologia,

UFPel. Pelotas RS Brasil.
Abstract This study aimed to describe the profile of motorcycle users and determine the prevalence of use. Also, to evaluate the reason for using a motorcycle, users' perceived risk of traffic accident, pattern of helmet wearing and number of accidents related to motorcycle use in the last 12 months. This cross-sectional study was conducted in the city of Pelotas, Southern Brazil. Sampling process was carried out in two stages, with the primary unit being the census track and the secondary the house. The study included 3,004 individuals aged 10 to 59 years, which answered a structured questionnaire. The outcome of the study was the use of motorcycle. The prevalence of motorcycle use was 25\%. The majority of the riders were composed by males (79\%). Individuals aged from 18 to 35-years-old comprised $42 \%$ of the total number of users, mainly as riders (24\%). Forty percent of the users were not using properly the helmet strap. The major part of the users (76\%) had a perception of high risk for accidents. The prevalence of accidents was 8\%; it was higher among males and among those individuals aged from 18 to 35 years. The use of motorcycle was widespread in the population. Users were aware of the risk of accident, even though they reported to not wear correctly the helmet.

Key words Motorcycles, Accidents, Traffic, Epidemiology, Public policies
Resumo Este estudo buscou descrever o perfil dos usuários de motocicleta e determinar a prevalência de uso desta. Além disso, avaliar a razão para o uso da motocicleta, o risco percebido de acidente de trânsito, o padrão de uso do capacete e o número de acidentes com injúrias ocorridos nos últimos 12 meses. Estudo transversal realizado na cidade de Pelotas com processo de amostragem conduzido em dois estágios. A primeira unidade foi o setor censitário e a segunda a casa dos indivíduos. Foram incluídos 3.004 indivíduos com idades entre 10 e 59 anos, que responderam um questionário estruturado. O desfecho do estudo foi o uso de motocicleta. A prevalência do uso de motocicleta foi de 25,1\%. A maioria dos motociclistas foi composta por homens (79\%). Indivíduos com idade entre 18 e 35 anos representaram 42\% do total de usuários, especialmente como motoristas (24\%), e $40 \%$ reportaram não usar adequadamente o capacete. A maior parte dos usuários (76\%) considerou estar em alto risco para acidentes. A prevalência de acidentes foi de $8 \%$, sendo mais alto entre os homens e entre os indivíduos com idade entre 18 a 35 anos. A motocicleta é amplamente usada nesta população. Usuários estão cientes do risco de acidentes, embora tenham reportado não usar o capacete de forma adequada.

Palavras-chave Motocicletas, Acidentes de trânsito, Epidemiologia, Políticas públicas 


\section{Introduction}

Brazil has suffered deep economical changes since the 1990s, which have led to the reduction of income inequalities and the increase of goods consumption among the poorer. The government policy against the economical crisis has started in 2008 and focused on reducing taxes and favouring access to bank credit ${ }^{1,2}$. In this context, the automobile and the motorcycle industries were among the targeted sectors to be benefited by this economical policy. In addition to that, few improvements in public transportation were made, thus it remained inefficient and relatively costly $y^{3,4}$.

Some factors may explain the $400 \%$ increase in motorcycles observed in Brazilian metropolis$\mathrm{es}^{5,6}$ since 2003: a) favoured access to bank credit; b) lower cost compared to cars; c) inneficieny of public transportantion. Thus, motorcycle was considered an alternative transportation. This increase, however, was accomplished by undesired consequences, such as high number of traffic accidents involving motorcycles, with many cases involving fatal victims ${ }^{7}$. According to the Brazilian laws, to ride a motorcycle individuals must be over 18 years-old; have specific license after being submitted to mandatory training; and always wear the helmet ${ }^{8}$.

In 2010, the World Health Organization (WHO) estimated more than 1,2 millions deaths caused due to traffic accidents. For 2030, traffic accidents are expected to be the $5^{\text {th }}$ cause of deaths ${ }^{9}$. In Brazil, external causes - where the traffic accidents are included - represented the second greater cause of deaths, being the first among individuals age 5 to 39 years-old ${ }^{10}$. National data revealed that the number of deaths and severe injuries has overcome 150 thousand individuals, with a total cost (social and economic) estimated in U\$ 28 billions $^{2,11}$. A recent study showed that between 1996 and 2009 the mortality rate increased from 0.5 to 4.5 per 100.000 habitants in Brazil - an increase of $800 \%$ in mortality rates during the period with a $19 \%$ average annual increase $^{12}$.

In order to prevent traffic accidents there is a need for more investigation in relation to the epidemiological patterns of motorcycle use. It is a concern to identify the most vulnerable individuals, especially in low- and middle-income countries, which are responsible for more than $90 \%$ of the traffic accidents in the world ${ }^{13,14}$. In Brazil, main victims of transit are motorcycle riders and pedestrians ${ }^{15}$. However, studies investigating the use of motorcycle and the prevalence of accidents in the country are mostly originated from emer- gency care services data ${ }^{16}$. Thus, it is essential to know the prevalence of use and the profile of these users to better evaluate the risks that those are submitted. It will allow the implementation of more effective public prevention policies.

Therefore, this study aimed to investigate the profile of motorcycle users - riders and passengers, and the prevalence of use. In addition, we aimed to evaluate the reason for using a motorcycle, users' perceived risk of traffic accident, pattern of helmet wearing and number of accidents related to motorcycle use in the last 12 months.

\section{Materials and methods}

Between January and June 2012, a populationbased cross-sectional study was carried out in the urban zone of Pelotas. The city is located in Southern Brazil, with an estimated population of 328,000 habitants ${ }^{17}$. This investigation was part of a general survey, involving different health outcomes $^{18}$. For the sample size calculation, it was estimated a prevalence of $20 \%$ for motorcycle use, based on the number of motorcycles registered in the traffic department (DETRAN-RS), with an acceptable error of 5 percentage points and a design effect of 2.0. The sample size was determined as 566 individuals, including 15\% for losses or refusals. The final sample included 3,920 individuals because the other outcomes investigated in the survey required higher sample.

The sample selection was performed in two stages and the primary stage unit was the census tracts from the last National Census ${ }^{17}$. One hundred and thirty, out of the 495 existents, census tracks were systematically sorted, and they were ordered by their geographic location. In these census tracks, all inhabited private houses were listed (excluding those without habitants and those only with commercial purposes), being systematically chosen 12 houses in each sector. In each house, all individuals aged 10 to 59 yearsold were interviewed, excluding those individuals physically impaired to use motorcycle and those mentally compromised to answer the questionnaire.

Data collection was made by previously trained interviewers, through visits to the individuals' houses. The research instrument was a structured questionnaire, previously tested, and composed by each specific outcome investigated. Moreover, a general section was related to socioeconomic and demographic information. Before individuals could be classified as a lost, they should be searched at least for three times. 
Motorcycle use was defined as the outcome of this study. Its use was registered if it was considered by the interviewed as the current option of transportation for any purpose, including leisure, commuting to work or study or familial transport. Motorcycle users were classified as riders or passengers. The non-habitual use of motorcycle was considered current use.

The independent variables collected were sex, age (complete years; subsequently categorized in adolescents (10-17 years); and adults (18-35 years/36-49 years/50-59 years), skin color (white/ dark black/light black/others), years of schooling (complete years of study; subsequently categorized in four categories: 0-4 years/5-8 years/9-11 years/12 years of more) and economical level (based on the IEN - Indicador Econômico Nacional/ National Wealth Score - in quintiles) ${ }^{19}$.

Also, the purpose of motorcycle use was investigated, with the following options: commuting to work or study; leisure; to conduct the children or relatives to school or work; work (motorcycle office boy or taxi) and other work requiring the use of motorcycle (for example sales promoter, post office workers/mailman).

The frequency of use (dependent variable) was characterized by the use of the motorcycle during the week, on the weekends or on both. The number of daily hours use was asked.

In relation helmet wearing, it was asked about how the individual kept the helmet strap fastened (properly used - fastened and tightened when starting to ride the motorcycle; not properly used - always closed but not fastened or never closed). In relation to risk of traffic accidents perception, a Likert scale was used, with five levels, ranging from very high risk to very low risk.

Motorcycle accident was defined as a traffic accident with injury to the motorcycle user, in a rider or in a passenger condition. These accidents included falls, collisions and pedestrians running over. The questionnaire focused on the accidents happened in the last 12 months and investigated the number of accidents. It was applied also including those individuals that stated not using a motorcycle currently. This was made in order to detect those individuals that were not using the motorcycle due to sequels or fear caused by previous accidents. These individuals were not included in the prevalence analysis.

Data quality control was carried out with the application of the question about current use of motorcycle to $10 \%$ of the sample size, randomly selected. For results comparison, kappa index was used.

Statistical analysis was performed using the STATA 12 software package (StataCorp., College
Station, TX, USA) using the svy command for conglomerate samples.

The study had the approval of the Federal University of Pelotas Ethic Committee. All the individuals included in the study have signed the informed consent form.

\section{Results}

In the 1,722 houses visited, 3,152 individuals aged from 10 to 59 years were found. From those, 3,004 were interviewed, resulting $13.2 \%$ of losses and refusals. No differences were observed between age groups, however it was higher amongst the males (57\%). The Design Effect (DEF) for the current use of motorcycle was 2.5. A kappa index of 0.81 was found for this question when comparing interview and quality control, indicating high repeatability.

Table 1 describes the sample interviewed. It shows a higher number of females $(56.1 \%)$ and age range between 18 and 49 years $(63.7 \%)$. Approximately $60 \%$ of the adults (individuals aged 18 -years or beyond) interviewed and $75 \%$ of the adolescents (individuals aged 10 to 17 -years-old) presented from 4 to 11 years of schooling. In relation to the 754 motorcycle users identified in the total sample, there was a predominance of men as riders $(79.8 \%)$ and women as passengers (73\%). Young adults (aged between 18 and 35 years) were half of the riders, while among the passengers the predominant age range was between 10 to 35 years $(68.4 \%)$. Eighteen adolescents $(5 \%)$ informed that they use the motorcycle as riders. Approximately $2 / 3$ of the riders were situated in the intermediate quintiles of income and the passengers were predominantly in the lower income level.

The prevalence of motorcycle use in the surveyed population was $25.1 \%$ (95\% CI 22.6-27.6) and according to the motorcycle condition use, rider or passenger, it was 12\% 95CI\% (10.6-13.4) and $13.1 \% 95 \mathrm{CI} \%$ (11.4-14.8), respectively.

Table 2 shows that the prevalence of use among the females was $21.3 \%$ 95CI\% (18.723.9 ), while among the males it was $29.9 \% 95 \mathrm{CI} \%$ (26.7-33.2). The rate of riders was 5 times higher among men compared to women (21.9 versus $4.3 \%, \mathrm{p}<0.001)$. In the passenger condition, the results were in the opposite way with a higher proportion of women compared to men (17.1 versus $8 \%, \mathrm{p}<0.001)$. Approximately $25 \%$ of the adolescents and adults aged 18 to 49 years old used the motorcycle. Among the older ones, the prevalence of use was lower (17.1\%). In general, 
Table 1. Description of total sample and the use of motorcycle according to socioeconomic and demographic variables and according to user condition (driver or rider). Pelotas, Brazil, 2012.

\begin{tabular}{|c|c|c|c|c|c|c|}
\hline \multirow{3}{*}{ Variables } & \multirow{2}{*}{\multicolumn{2}{|c|}{$\begin{array}{c}\text { General } \\
\text { Total Sample }\end{array}$}} & \multicolumn{4}{|c|}{ Motorcycle user condition } \\
\hline & & & \multicolumn{2}{|c|}{ Rider } & \multicolumn{2}{|c|}{ Passenger } \\
\hline & $\mathbf{N}$ & $\%$ & $\mathbf{N}$ & $\%$ & $\mathbf{N}$ & $\%$ \\
\hline \multicolumn{7}{|l|}{ Sex } \\
\hline Male & 1320 & 43.9 & 289 & 79.8 & 106 & 27.0 \\
\hline Female & 1684 & 56.1 & 72 & 20.2 & 287 & 73.0 \\
\hline \multicolumn{7}{|l|}{ Skin color } \\
\hline White & 2360 & 78.6 & 287 & 79.5 & 293 & 74.6 \\
\hline Dark black skinned & 390 & 13.0 & 42 & 11.6 & 61 & 15.5 \\
\hline Light black skinned & 219 & 7.3 & 27 & 7.5 & 33 & 8.4 \\
\hline Others & 35 & 1.2 & 5 & 1.4 & 6 & 1.5 \\
\hline \multicolumn{7}{|l|}{ Age } \\
\hline 10-17 years & 576 & 19.2 & 18 & 5.0 & 133 & 33.8 \\
\hline $18-35$ years & 1111 & 37.0 & 181 & 50.1 & 136 & 34.6 \\
\hline $36-49$ years & 803 & 26.7 & 120 & 33.2 & 78 & 19.9 \\
\hline $50-59$ years & 514 & 17.1 & 42 & 11.6 & 46 & 11.7 \\
\hline \multicolumn{7}{|c|}{ Years of Schooling - Adults $(\mathrm{N}=2260)$} \\
\hline $0-4$ years & 237 & 10.5 & 23 & 7.1 & 24 & 10.7 \\
\hline $5-8$ years & 635 & 28.1 & 112 & 34.5 & 71 & 31.6 \\
\hline $9-11$ years & 706 & 31.2 & 130 & 40.0 & 87 & 38.7 \\
\hline 12 years or more & 682 & 30.2 & 60 & 18.5 & 43 & 19.1 \\
\hline \multicolumn{7}{|c|}{ Years of Schooling - Adolescents $(\mathrm{N}=576)$} \\
\hline $0-4$ years & 119 & 20.6 & 4 & 22.2 & 22 & 16.5 \\
\hline $5-8$ years & 341 & 59.2 & 14 & 77.8 & 93 & 69.9 \\
\hline $9-11$ years & 109 & 18.9 & - & - & 17 & 12.8 \\
\hline 12 years or more & 7 & 1.2 & - & - & 1 & 0.8 \\
\hline \multicolumn{7}{|l|}{ IEN 5quintiles } \\
\hline 1 (20\% poorer) & 552 & 18.5 & 69 & 19.2 & 94 & 24.0 \\
\hline 2 & 592 & 19.9 & 62 & 17.2 & 81 & 20.7 \\
\hline 3 & 626 & 21.0 & 82 & 22.8 & 86 & 22.0 \\
\hline 4 & 600 & 20.1 & 88 & 24.4 & 84 & 21.5 \\
\hline 5 (20\% richer) & 609 & 20.4 & 59 & 16.4 & 46 & 11.7 \\
\hline Total & 3004 & & 361 & & 393 & \\
\hline
\end{tabular}

riders were aged 18 to 35 years $(16.3 \%)$ and 36 to 49 years $(15 \%)(\mathrm{p}<0.001)$. Among adolescents, $23.1 \%$ used the motorcycle in the passenger condition, and there was a decrease in the prevalence of passenger condition with aging, since it was reported by only $9 \%$ of the individuals aged 50 to 59 years. The prevalence of motorcycle use for both conditions, as rider or passenger, was lower in the richest quintile $(17.2 \%)$

The prevalence of accidents in the last 12 months was $8 \%$ (95CI\% 5.6-10.3). Among men and women the occurrence was $10.6 \%$ and $5 \%$, respectively $(\mathrm{p}<0.001)$. The highest proportion of accidents happened in the age group of 18 to 35 years $(12.3 \%)$. The prevalence of accidents in riders was $13.9 \%(95 \% \mathrm{CI}$ 9.8-17.9) and 2.5\% (95\%CI 0.8-4.2) in passengers (data not shown).
In the survey, it was noted 21 accident victims that were not using the motorcycle currently due to previous accidents. If those individuals were included in the analysis, the prevalence of accident would be $10.5 \%$ (95\%CI 8.4-12.8)

Table 3 shows that $75.9 \%$ of the users had a perception of very high or high risk of suffering a traffic accident. The large majority $(62.4 \%)$ reported to use the motorcycle for less than 1 hour /day and 6.5\% used for more than 4 hours/daily. Half of the sample (49.9\%) used the motorcycle during the week and on the weekends. More than $40 \%$ reported wearing the helmet without adjusting the strap properly or they have not fastened the strap.

The reasons for motorcycle use are described in Table 4. More than half of the users, have indi- 
Table 2. Prevalence of motorcycle use in general and for condition (driver or rider) and traffic accidents related, according to socioeconomic and demographic condition. Pelotas, Brazil, 2012.

\begin{tabular}{|c|c|c|c|c|c|c|c|c|}
\hline \multirow{3}{*}{ Variables } & \multicolumn{6}{|c|}{ Motorcycle use } & \multirow{2}{*}{\multicolumn{2}{|c|}{$\begin{array}{c}\text { Accidents last } \\
12 \text { months }\end{array}$}} \\
\hline & \multicolumn{2}{|c|}{ Total } & \multicolumn{2}{|c|}{ Rider } & \multicolumn{2}{|c|}{ Passenger } & & \\
\hline & $\mathbf{N}$ & $\%$ & $\mathrm{~N}$ & $\%$ & $\mathbf{N}$ & $\%$ & $\mathbf{N}$ & $\%$ \\
\hline Sex & $\mathrm{p}<0.001$ & & $\mathrm{p}<0,001$ & & $\mathrm{p}<0,001$ & & $\mathrm{p}<0,001$ & \\
\hline Male & 395 & 29,9 & 289 & 21,9 & 106 & 8,0 & 42 & 10,6 \\
\hline Female & 359 & 21,3 & 72 & 4,3 & 287 & 17,1 & 18 & 5,0 \\
\hline Skin color & $\mathrm{p}=0,717$ & & $\mathrm{p}=0,843$ & & $\mathrm{p}=0,5113$ & & $\mathrm{p}=0,690$ & \\
\hline White & 580 & 24,6 & 287 & 12,2 & 293 & 12,4 & 49 & 8,5 \\
\hline Dark black skinned & 103 & 26,4 & 42 & 10,8 & 61 & 15,6 & 7 & 6,8 \\
\hline Light black skinned & 60 & 27,4 & 27 & 12,3 & 33 & 15,1 & 4 & 6,7 \\
\hline Others & 11 & 31,4 & 5 & 14,3 & 6 & 17,1 & - & - \\
\hline Age & $\mathrm{p}<0,001$ & & $\mathrm{p}<0,001$ & & $\mathrm{p}<0,001^{* *}$ & & $\mathrm{p}<0,001$ & \\
\hline 10-17 years & 151 & 26,2 & 18 & 3,1 & 133 & 23,1 & 3 & 2,0 \\
\hline $18-35$ years & 317 & 28,5 & 181 & 16,3 & 136 & 12,2 & 39 & 12,3 \\
\hline $36-49$ years & 198 & 24,7 & 120 & 15,0 & 78 & 9,7 & 14 & 7,1 \\
\hline 50-59 years & 88 & 17,1 & 42 & 8,2 & 46 & 9,0 & 4 & 4,6 \\
\hline Schooling ${ }^{* *}$ & $\mathrm{p}<0,001$ & & $\mathrm{p}<0,001$ & & $\mathrm{p}<0,001$ & & $\mathrm{p}=0,333$ & \\
\hline $0-4$ years & 47 & 19,9 & 23 & 9,8 & 24 & 10,2 & 4 & 8,5 \\
\hline $5-8$ years & 183 & 28,8 & 112 & 17,6 & 71 & 11,2 & 10 & 5,5 \\
\hline $9-11$ years & 217 & 30,7 & 130 & 18,4 & 87 & 12,3 & 23 & 10,6 \\
\hline 12 years or more & 103 & 15,1 & 60 & 8,8 & 43 & 6,3 & 8 & 7,8 \\
\hline IEN (quintiles) & $\mathrm{p}=0,02$ & & $\mathrm{p}=0,081$ & & $\mathrm{p}=0,002$ & & $\mathrm{p}=0,647$ & \\
\hline 1 (20\% poorer) & 163 & 29,5 & 69 & 12,5 & 94 & 17,0 & 15 & 9,2 \\
\hline 2 & 143 & 24,2 & 62 & 10,5 & 81 & 13,7 & 8 & 5,6 \\
\hline 3 & 168 & 26,9 & 82 & 13,1 & 86 & 13,8 & 13 & 7,7 \\
\hline 4 & 172 & 28,7 & 88 & 14,7 & 84 & 14,0 & 14 & 8,1 \\
\hline 5 (20\% richer) & 105 & 17,2 & 59 & 9,7 & 46 & 7,6 & 10 & 9,5 \\
\hline Total & 754 & & 395 & & 359 & & 60 & \\
\hline
\end{tabular}

"Values of p obtained by Poisson regression, using the svy command for conglomerate samples. " $\mathrm{p}$ value of linear trend. ${ }^{* * *}$ only for adults (20 years or more).

cated the use for commuting to work or study; almost $15 \%$ used to conduct children and relatives to school or work; $75 \%$ used for leisure and only $2 \%$ had the motorcycle as their tool for work, like taxi or motorized office boys.

\section{Discussion}

The main finding of this study was that motorcycle users (riders and passengers) had a widespread distribution in the investigated population, meaning that men and women of several ages and from different socioeconomic classes are using motorcycle. The increased number of motorcycles was not followed by public policies focusing on this specific vehicle $e^{9,15,16,20,21}$. According to the literature, motorcycle users have 7 times greater risk of death and 4 times higher risk of body lesion when compared to automobile users ${ }^{15}$. In five Brazilian metropolises it was observed that in $61 \%$ to $82 \%$ accidents involving motorcycle, there were victims, while in automobile accidents this rate was lower ${ }^{2}$. Such finding clearly demonstrates the risk involved when motorcycles are used. National data from Brazil shows that the number of motorcycle on the streets has increased 4 times from 2008 to $2011^{22}$. As a consequence, there was an expressive increase of $350 \%$ in the deaths caused by motorcycle use from 2000 to $2010^{15}$. The increased number of motorcycles in the country could be attributed to the inefficiency and high cost of public transportation in addition to the bank credit benefit to purchase a new vehicle. The amount of money paid monthly to get a new vehicle is similar to the cost of public transportation, besides the user has the feeling of more freedom and independence in his own vehi$\mathrm{cle}^{23}$. Around $40 \%$ of the individuals that bought a motorcycle in 2012 in Brazil had the purpose to 
Table 3. Characteristics of motorcycle use in relation to the daily use, perception of risk for accidents, frequency of use and use of helmet. Pelotas, Brazil, 2012. $(\mathrm{n}=754)$

\begin{tabular}{lrr}
\hline \multicolumn{1}{c}{ Variables } & N & \% \\
\hline Perception of risk & & \\
$\quad$ Very high & 333 & 44.2 \\
High & 239 & 31.7 \\
Medium & 136 & 18.1 \\
Low & 34 & 4.5 \\
$\quad$ Very low & 11 & 1.5 \\
Daily hours use & & \\
Up to one hour & 470 & 62.4 \\
Two to three hours & 231 & 30.1 \\
$\quad$ More than 4 hours & 49 & 6.5 \\
Frequency of use & & \\
$\quad$ Weekdays & 222 & 29.5 \\
$\quad$ Weekends & 156 & 20.8 \\
$\quad$ Both & 375 & 49.9 \\
Helmet strap & & \\
$\quad$ Fastened and tightened when & 426 & 56.6 \\
$\quad$ starting to ride the motorcycle & & \\
$\quad$ Always closed but not fastened & 276 & 36.6 \\
$\quad$ Never closed & 51 & 6.7 \\
\hline
\end{tabular}

Table 4. Reason for motorcycle use. Pelotas, Brazil, 2012. $(\mathrm{n}=754)$.

\begin{tabular}{lrr}
\hline \multicolumn{1}{c}{ Variables } & N & \% \\
\hline Reason for use & & \\
$\quad$ Commuting to work or school & 434 & 57.4 \\
Leisure & 559 & 75.9 \\
Children of relatives transportation & 110 & 14.6 \\
Motored office boy or taxi & 16 & 2.2 \\
Other kind of work & 26 & 3.4 \\
\hline
\end{tabular}

replace the use of public transportation, according to the National Association of Motorcycle Producers $^{22}$. Thus, motorcycle should be considered the true popular transportation in Brazil ${ }^{23}$.

Our findings demonstrated that the proportion of men and women using the motorcycle is similar; however, a huge difference is observed in role played by them. While men were predominantly riders, women were mostly passengers. Despite of that, this study showed a high rate of female among the drivers (more than 20\%), compatible with the data from motorcycle buyers $(25 \% \text { in } 2011)^{22}$. Therefore, it is essential that approaches leading to accident prevention should also be directed to females. Another population based study ${ }^{24}$ carried out in Iran found less than $4 \%$ of women riders, but this difference could be related to cultural differences between the countries and also related to the role that women play in the society.

We expected that motorcycle users would be young individuals from the lowest socioeconomic position. However, the present study demonstrated that motorcycle use was distributed homogenously in the population, revealing that there is not a specific pattern for motorcycle uses. Despite of the low prevalence of motorcycle use for work in our study, previous studies have suggested that this type of activity was responsible for increasing the number of traffic accidents ${ }^{25-27}$. In this specific population, other purposes appeared to be more relevant causes, since families have motorcycles as their first transportation option (work/school and leisure). Almost 50\% of those interviewed reported to use motorcycles on weekdays and weekends, suggesting that motorcycle is the main transportation vehicle. It was also possible to verify that individuals that less often use motorcycles are the $20 \%$ richer and those above 50 years old. It is also alarming that $5 \%$ of motorcycle riders were below 18-years-old, which is the minimum age to legally drive in Brazil. This fact emphasizes the lack of surveillance by the Brazilian traffic authority ${ }^{13,15}$. Moreover, the predominately daily use was shorter than one hour, turning clear that the focus of the public policies to prevent traffic accidents should be on the large number of users and not on the amount of time individuals are spending over the motorcycle.

Even though the large majority has declared that the risk for accidents is very high or high, individuals continue to elect the motorcycle as the main vehicle. Subjects prefer the motorcycle because of its rapid and easy dislodgement, with a better cost/benefit when compared to public transportation ${ }^{3,4}$. However, motorcyclists should be faced as a vulnerable group in the traffic context, once the vehicle has no additional security equipment apart from the helmet ${ }^{28}$. This risk should be perceived in order to make decision and change risky behaviors ${ }^{29}$. Therefore, it is necessary people believe that safety measurements are effective, influencing them to use properly the protection equipment and to respect the laws.

Although, a high risk of accident was perceived in the sample, almost half of the users are not properly wearing the helmet. In 2013, the Brazilian National Transit Council (CONTRAN) released official instructions regarding the adequate helmet wearing and its mandatory use for motorcyclists. According to the document, the 
helmet should be adequately placed, with the strap fastened under the lower $\mathrm{jaw}^{30}$. The incorrect use of the helmet can produce an undesirable effect; the helmet can be launched to distance in the case of an accident, inhibiting its protective effect $^{30}$. Also, the type of helmet should be considered, since open-face helmets did not always offer adequate protection against craniomaxillofacial injury even when used properly ${ }^{31}$.

Considering the accidents, our results corroborate the findings from studies carried out in emergence care services and hospitals. They indicated that young males are the most frequent victims $^{7,9,15,20,21,32-37}$, due the proper characteristics of youth, such as the impulsivity and necessity of self-affirmation ${ }^{34}$. These data reinforce the concerns demonstrated by the WHO in relation to the morbidity/mortality for external causes in which young males are the priority focus of prevention ${ }^{16,30}$. Our findings support the importance of public health policies in order to prevent the motorcycle accidents. The cost for the individuals and for the public heath system to treat those suffering motorcycle accidents is very high. This is a concern not only in Brazil, but also in other lowand middle-income countries where there is a widespread use of motorcycles. Mortality among Brazilian motorcyclists increased by more than 700\% between 1998 and 2008 ${ }^{15}$. Hospitalizations covered by the Brazilian Unified Health System due to motorcycle accidents had an increase of $83 \%$ in five years. In the same period, the increase in hospitalizations due to all types of road accidents was about $9 \%{ }^{25}$.

\section{Collaborations}

LM Seerig, G Bacchieri, GG Nascimento, AJD Barros and FF Demarco participated equally in all stages of preparation of the article.
This study is not free of limitations. First, information collected was self-reported. Thus, it can be in some degree affected by recall bias. Second, the cross-sectional design of the present study could not allow the establishment of a historic and trend of motorcycle use; neither to identify changes in the users profile. Finally, it was not possible to collect precisely the reason why some individuals were not using motorcycle anymore.

This study has several strengths that should be emphasized. Initially, the sampling process allowed the knowledge of population data, without the bias of taking data from emergency care services or from hospitals. This assures internal validity of our findings and avoids the overestimation of accidents. Also, the city of Pelotas has characteristics - Index of Human Development (0.81), schooling level, age variation groups and income level - which are similar to the major part of Brazilian cities. Thus, our findings could be extrapolated to other cities with similar profile.

The World Health Organization ${ }^{9}$ has reinforced the need of producing epidemiological data that are the basis for formulation of public policies for accident prevention. Findings revealed in our study are within the scope requested by the WHO; thus it can be useful to produce public policies in Brazil and also in other countries experiencing similar issues. Public policies for motorcycle accidents prevention should be as effective as the market policies toward the increase of motorcycle selling. Stricter rules to obtain drivers' license, effective transit surveillance, and investments in traffic engineering are fundamental actions to enhance the safety of motorcycle use.

\section{References}

1. Figueiredo EA, Ziegelmann FA. Mudança na distribuição de renda brasileira: significância estatística e bem -estar econômico. Econ Apl 2009; 13(2):257-277.

2. Brasil. Instituto de Pesquisa Econômica Aplicada (IPEA). Impactos Sociais e Econômicos dos Acidentes de Trânsito nas Aglomerações Urbanas. Brasília: IPEA; 2003. Relatório.

3. Azambuja AMV. Análise de eficiência na gestão do transporte urbano por ônibus em municípios brasileiros [tese]. Florianópolis: Universidade Federal de Santa Catarina; 2002.

4. Scaringella RS. A crise da mobilidade urbana em São Paulo. Sao Paulo Persp 2001; 15(1):55-59.

5. Brasil. Ministério das Cidades. Departamento Estadual de Trânsito do Rio Grande do Sul (DETRAN). [site da internet]. [acessado 2015 maio 8]. Disponível em: http://www.detran-rs.gov.br 
6. Brasil. Ministério das Cidades. Departamento Nacional de Trânsito. Impactos sociais e econômicos dos acidentes de trânsito nas rodovias brasileiras. [site da internet]. [acessado 2015 maio 8]. Disponível em: http://www.denatran.gov.br/publicacoes/download/ custos_acidentes_transito.pdf

7. Pordeus AMJ, Vieira LJES, Almeida PC, Andrade LM, Silva ACG, Lira SVG. Associated factors to the occurrence of motorcycle accident in the perception of hospitalized motorcyclist. Rev Bras Promocao Saude 2010; 23(3).

8. Duarte EC, Garcia LP. Adolescent drivers in Brazil: prevalence and associated factors estimated from the National Adolescent School-based Health Survey (PeNSE 2012). Rev Bras Epidemiol 2014; 17(Supl. 1):316.

9. World Health Organization (WHO). Global status report on road safety 2013: suporting a decade of action. [site da internet]. [acessado 2015 maio 8]. Disponível em: http:// www.who.int/violence_injury_prevention/road_safety_status/2013/en/ 2013

10. Brasil. Ministério da Saúde (MS). Departamento de Informática do SUS (DATASUS). [site da internet]. [acessado 2015 fev 14]. Disponível em: http://www. datasus.gov.br

11. Brasil. Ministério da Saúde (MS). Departamento de Informática do SUS (DATASUS). Gastos Internação Causas Externas. [site da internet]. [acessado $2015 \mathrm{fev}$ 14]. Disponível em: http://www.datasus.gov.br

12. Martins ET, Boing AF, Peres MA. Motorcycle accident mortality time trends in Brazil, 1996-2009. Rev Saude Publica 2013; 47(5):931-941.

13. Ameratunga S, Hijar M, Norton R. Road-traffic injuries: confronting disparities to address a global-health problem. Lancet 2006; 367(9521):1533-1540.

14. Nantulya VM, Reich MR. The neglected epidemic: road traffic injuries in developing countries. BMJ 2002 324(7346):1139-1141.

15. Bacchieri G, Barros AJD. Acidentes de trânsito no Brasil de 1998 a 2010: muitas mudanças e poucos resultados. Rev Saude Publica 2011; 45(5):949-963.

16. Waiselfísz JJ. Mapa da violência: Os jovens da América Latina. [site da internet]. [acessado 2015 fev 14]. Disponível em: www.mapadaviolencia.org.br/publicacoes/Mapa_2008_al.pdf. 2008

17. Instituto Brasileiro de Geografia e Estatística (IBGE). Contagem Populacional. [site da internet]. [acessado 2015 mar 22]. Disponível em: http://censo2010.ibge. gov.br/resultados

18. Barros AJD, Menezes AMB, Santos IS, Assunção MCF, Gigante D, Fassa AG, Marques M, Araújo C, Hallal PC, Facchini LA. O Mestrado do Programa de Pós-graduação em Epidemiologia da UFPel baseado em consórcio de pesquisa: uma experiência inovadora. Rev Bras Epidemiol 2008; 11(Supl. 1):133-144.

19. Barros AJD, Victora CG. Indicador econômico para o Brasil baseado no censo demográfico de 2000. Rev Saude Publica 2005; 39(4):523-529.

20. Oliveira NLB, Sousa RMC. Diagnóstico de lesões e qualidade de vida de motociclistas, vítimas de acidentes de trânsito. Rev Latino-Am Enfermagem 2003; 11(6):749756.

21. Rolison JJ, Hewson PJ, Hellier E, Hurst L. Risks of high-powered motorcycles among younger adults. Am J Public Health 2013; 103(3):568-571.
22. Associação Brasileira dos Fabricantes de Motocicletas, Ciclomotores, Motonetas, Bicicletas e Similares (ABRACICLO). Dados sobre motociclistas. [site da internet]. [acessado $2014 \mathrm{dez} 08$ ]. Disponível em: http:// www.abraciclo.com.br

23. Sant'Anna FL, Andrade SM, Sant'Anna FH, Liberatti CL. Motorcycle accidents: comparison between the years 1998 and 2010 in Londrina, Southern Brazil. Rev Saude Publica 2013; 47(3):607-615.

24. Saadat S, Soori H. Epidemiology of traffic injuries and motor vehicles utilization in the Capital of Iran: A population based study. BMC Public Health. 2011; 11(1):488.

25. Mello Jorge M, Koizumi M. Motos no trânsito brasileiro: do lazer à ferramenta de trabalho. Rev ABRAMET 2007; 25:12-21.

26. Silva DW, Andrade SM, Soares DA, Nunes EFP, Melchior R. Condições de trabalho e riscos no trânsito urbano na ótica de trabalhadores motociclistas. Physis 2008; 18(2):339-360.

27. Silva DW, Andrade SM, Soares DA, Soares DFPP, Mathias TAF. Perfil do trabalho e acidentes de trânsito entre motociclistas de entregas em dois municípios de médio porte do Estado do Paraná, Brasil. Cad Saude Publica 2008; 24(11):2643-52.

28. Rocha GS, Schor N. Motorcycle accidents in the municipality of Rio Branco in the State of Acre: characterization and trends. Cien Saude Colet 2013; 18(3):721-731.

29. Thielen IP, Hartmann RC, Soares DP. Percepção de risco e excesso de velocidade. Cad Saude Publica 2008; 24(1):131-139.

30. Brasil. Conselho Nacional de Trânsito (CONTRAN) [site da internet]. [acessado $2014 \mathrm{dez}$ 8]. Disponível em: http://www.denatran.gov.br/resolucoes.htm

31. Albuquerque CEL, Arcanjo FPN, Cristino-Filho G, Lopes-Filho AMA, de Almeida PC, Prado R, Pereira-Stabile CL. How safe is your motorcycle helmet? J Oral Maxillofac Surg 2014; 72(3):542-549.

32. Bastos YGL, Andrade SM, Soares DA. Características dos acidentes de trânsito e das vítimas atendidas em serviço pré-hospitalar em cidade do Sul do Brasil, 1997/2000. Cad Saude Publica 2005; 21(3):815-822.

33. Dall'aglio JS. Aspectos epidemiológicos dos acidentes de trânsito em Uberlândia, MG, 2000. Biosci J 2010; 26(3):484-490.

34. Pinto AD, Witt RR. Gravidade de lesões e características de motociclistas atendidos em um hospital de pronto socorro. Rev Gaucha Enferm 2008; 29(3):408.

35. Oliveira AL, Petroianu A, Gonçalves DM, Pereira GA, Alberti LR. Characteristics of motorcyclists involved in accidents between motorcycles and automobiles. Rev Assoc Med Bras 2015; 61(1):61-64.

36. Oliveira ZC, Mota ELA, Costa MCN. Evolução dos acidentes de trânsito em um grande centro urbano, 19912000. Cad Saude Publica 2008; 24(2):364-372.

37. Santos AMR, Moura MEB, Nunes BMVT, Leal CFS, Teles JBM. Perfil das vítimas de trauma por acidente de moto atendidas em um serviço público de emergência. Cad Saude Publica 2008; 24(8):1927-1938.

Artigo apresentado em 17/09/2015

Aprovado em 14/03/2016

Versão final apresentada em 16/03/2016 